\title{
Natural Disasters, Ecological Knowledge, and COVID-19 in the Philippines
}

\author{
Jan Gresil Kahambing, PHL, MA, STHB $\odot$
}

\author{
Instructor and Research Coordinator for the \\ Social Sciences and Values Education, Leyte \\ Normal University, Tacloban City, Philippines \\ Correspondence: \\ Jan Gresil Kahambing, PHL, MA, STHB \\ Social Sciences and Values Education \\ Leyte Normal University \\ Paterno Street, Tacloban City, \\ Philippines, 6500 \\ E-mail: jan_kahambing@lnu.edu.ph
}

Conflicts of interest/funding: none

Keywords: extreme weather events; pandemic; recovery

Abbreviation:

COVID-19: coronavirus disease 2019

Received: April 13, 2021

Revised: June 17, 2021

Accepted: June 21, 2021

doi:10.1017/S1049023X21000753

(C) The Author(s), 2021. Published by

Cambridge University Press on behalf of the

World Association for Disaster and Emergency Medicine.
Kahambing JG. Natural disasters, ecological knowledge, and COVID-19 in the Philippines. Prehosp Disaster Med. 2021;36(5):657-658.

In 2000-2019, the Philippines, following the top three countries Puerto Rico, Myanmar, and Haiti, ranked fourth among the countries most affected by extreme weather events. Reports of loss and suffering, as well as economic and health damages, indicate long-term reconstructions and recovery, as emphasized by a previous article on Honduras' natural disasters amid the coronavirus disease 2019 (COVID-19) pandemic. ${ }^{1}$ What makes recovery difficult is that the Philippines, along with Haiti and Pakistan, have recurrent catastrophes that make it continuously ranked, according to the Global Climate Risk Index 2021, as most affected both "in the long-term index and in the index for each respective year." ${ }^{2}$ The country in recent memory has been exposed to Super Typhoon Yolanda (International name: Haiyan) in 2013, and post-Haiyan efforts are still in place. With Malawi, India, Niger, and Nepal, national and local disaster risk reduction strategies are still being integrated fully in the country. This scenario makes the pandemic crisis extra difficult to handle.

In the Philippines, the last-quarter of every year has been proven to be more frequented by tropical cyclones. ${ }^{3}$ In 2020, a year plagued by the pandemic crisis, Typhoon Ambo (International name: Vongfong) did the opening salvo (active: May 11-17, 2020) with more than 100,000 people displaced, striking familiar waves of loss and damage, and with strength almost comparable to Haiyan that it was called "Yolanda, Jr." During this pandemic, indigenous communities in the region who had experienced Haiyan may have their own ecological knowledge $e^{5,6}$ which could contribute largely today (ie, recall how recently the stuck Ever Given ship was rescued in the Suez Canal through the help of local knowledge about the tides), but their plea for help still calls for a more integrated response from agencies. ${ }^{7}$ The "double-whammy" experience in Ambo, which characterizes the pandemic and storms as two natural vulnerabilities, ${ }^{8}$ was followed by three more strong typhoons, namely: Quinta (International name: Molave), Rolly (International name: Goni), and Ulysses (International name: Vamco). They were active mostly from the northern region of Luzon from October 25-November 12, 2020, with a short interim from November 3-8 only. The retirement (a process of removing typhoon nominal tags due to significant impact) of the four names capped a sum of $\$ 950$ million worth of damage.

The question of whether COVID-19 is a message from nature can be rejoined in the aspects of human responsibility and relations of oneness to the Earth - lessons that are learned in indigenous ecological knowledge either in Australia ${ }^{9}$ or the Philippines. ${ }^{10}$ For example, human activities like deforestation have allowed for wildlife viruses to be transferred to humans. In this sense, claims about the Anthropocene - where humans play a dominating role in climate change - and its ethical considerations ${ }^{11}$ in prospecting policies or interventions are not wrong to suppose an anthropocentric mediating responsibility to care for the Earth. The fact that ecological knowledge contributes to disaster ethics makes it all the more pressing to inhabit a sense of interdisciplinary disposition. The lesson of oneness is critical and different fields can complement each other. In the pandemic, the role of language, for instance, and the way we craft certain agendas for the environment is crucial. ${ }^{12}$

It is becoming the case that advocacies grounded on the frontline of the pandemic and disasters must anticipate and mitigate not only the double, but multiple, risks that the current situation has already revealed. The Philippines has had a greater rise of new cases in March and April 2021 with on-going active statuses, including deaths. Supplementary to the predicaments are old and new problems, such as vaccine hesitancies, vaccine distribution hurdles for the poor, corruption, new mutations of the virus, strenuous problems in the education sector, food security, suicides, stigmatizations, and socioeconomic challenges.

There will be threats of faux pas in every collective action so that political agendas need empirically-based motivations and more humanitarian considerations. Expediting efforts 
might not be easy because of bureaucratic processes, but there should be balance in the way speed and thoroughness are operated. How that balance can be achieved depends largely on comprehensive, rational, and practical executive and legal implementations taking into account an integrated response on the ground.

\section{References}

1. Zambrano LI, Fuentes-Barahona IC, Henriquez-Marquez KI, et al. COVID-19 and hurricanes: the impact of natural disasters during a pandemic in Honduras, Central America. Prehosp Disaster Med. 2021;36(2):246-248.

2. Eckstein D, Künzel V, Schäfer L. Global Climate Risk Index 2021. Who Suffers Most from Extreme Weather Events? Weather-Related Loss Events in 2019 and 2000-2019. Bonn, Germany: Germanwatch; 2021.

3. Kahambing JGS. Tropical cyclones and children during a pandemic in the Philippines. Asia Pac J Public Health. 2020;32(8):507.

4. Kahambing JGS. Public health and local emergency ethics: vulnerability in Eastern Samar, Philippines. Public Health. 2020;185:117-118.

5. Kahambing JG. Learning to bury the dead during COVID-19 - Barbarism or indigeneity? Prehosp Disaster Med. 2020;35(6):702-703.

6. Kahambing J. "Diaspora as Vanishing Mediator: Emancipation of Identity for the Mamanuas of Basey, Samar.” In Galang-Pereña F, Ampil R, Gonzales E, LazaroZamora N, (eds). Philippines and Asian Studies: Expositions, Explorations, and

Expectations. Rizal, Philippines: Word Prints Publishing Services, Inc; pp. 183-200.

7. KahambingJ. Theorizing Mamanuan Diaspora: from vanishing mediator to performative indigeneity. Rupkatha Journal on Interdisciplinary Studies in Humanities. 2020;11(2):1-15.

8. Kahambing JG. COVID-19, natural vulnerability, and zugzwang. $J$ Public Health (Oxf). 2021;43(2):e252-e253.

9. Weckert J. Is COVID-19 a message from nature? NanoEthics. 2020;14:129-133.

10. Elicor P. Philosophical inquiry with indigenous children: an attempt to integrate indigenous knowledge in philosophy for/with children. Childhood Philosophy. 2019;15:1-22.

11. Kahambing J. Living the Anthropocene from the 'end of nature' to ethical prospects. Eubios J Asian Int Bioethics. 2019;29(4):145-149.

12. Kahambing JG. Metonymies, metaphors, and/or language reconsiderations for sustainability during COVID-19. J Public Health (Oxf). 2021. Epub ahead of print. 